\title{
Correction to: Osteoarthritis Preoperative Package for care of Orthotics, Rehabilitation, Topical and oral agent Usage and Nutrition to Improve ouTcomes at a Year (OPPORTUNITY); a feasibility study protocol for a randomised controlled trial
}

\author{
A. Hamish R. W. Simpson ${ }^{1 *}$, Colin R. Howie ${ }^{1 \dagger}$, Elaine Kinsella², David F. Hamilton ${ }^{1 \dagger}$, Philip G. Conaghan ${ }^{3 \dagger}$, \\ Catherine Hankey ${ }^{4 \dagger}$, Sharon Anne Simpson ${ }^{4 \dagger}$, Anna Bell-Higgs ${ }^{5 \dagger}$, Peter Craig ${ }^{4 \dagger}$, Nicholas D. Clement ${ }^{1}$, \\ Catriona Keerie ${ }^{2}$, Sarah R. Kingsbury ${ }^{3+}$, Anthony R. Leeds ${ }^{6+}$, Hazel M. Ross ${ }^{5+}$, Hemant G. Pandit ${ }^{3+}$, Chris Tuck ${ }^{2+}$ and \\ John Norrie ${ }^{2 \dagger}$
}

Correction to: Trials

https://doi.org/10.1186/s13063-019-3709-5

After publication of our article [1] we have been notified that two of the author names have been mistakenly removed from the authorship list: Colin R. Howie and Nicholas D. Clement.

The order of the authors has also been corrected.

Initially published authorship:

A. Hamish R. W. Simpson1*, Anna Bell-Higgs2†, Philip G. Conaghan3+, Peter Craig4t, David F. Hamilton1†, Catherine Hankey4+, Catriona Keerie5, Sarah R. Kingsbury3+, Elaine Kinsella5, Anthony R. Leeds6t, John Norrie5t, Hemant G. Pandit3†, Hazel M. Ross2†, Sharon Anne Simpson4† and Chris Tuck5t.

The original article can be found online at https://doi.org/10.1186/s13063019-3709-5

* Correspondence: hamish.simpson@ed.ac.uk

${ }^{\dagger}$ David F. Hamilton, Colin R. Howie, Philip G. Conaghan, Catherine Hankey, Sharon Anne Simpson, Anna Bell-Higgs, Peter Craig, Sarah R. Kingsbury, Anthony R. Leeds, Hazel M. Ross, Hemant G. Pandit, Chris Tuck and John Norrie contributed equally to this work.

${ }^{1}$ Department of Trauma and Orthopaedics, University of Edinburgh, Chancellor's Building, 49 Little France Crescent, Edinburgh EH16 4SB, UK

Full list of author information is available at the end of the article

\begin{abstract}
Author details
'Department of Trauma and Orthopaedics, University of Edinburgh, Chancellor's Building, 49 Little France Crescent, Edinburgh EH16 4SB, UK. ${ }^{2}$ Edinburgh Clinical Trials Unit, University of Edinburgh, Usher Institute, Level 2, Nine Edinburgh BioQuarter, 9 Little France Road, Edinburgh EH16 4UX, UK. ${ }^{3}$ Leeds Institute of Rheumatic and Musculoskeletal Medicine and NIHR Leeds Biomedical Research Centre, University of Leeds, 2nd Floor, Chapel Allerton Hospital, Chapeltown Road, Leeds LS7 4SA, UK. ${ }^{4}$ MRC/CSO Social and Public Health Sciences Unit, University of Glasgow, 200 Renfield Street, Glasgow G2 3QB, UK. ${ }^{5}$ Counterweight Ltd, 85 Great Portland Street, First Floor, London W1W 7LT, UK. ${ }^{6}$ The Parker (arthritis) Institute, Copenhagen University Hospital, Bispebjerg og Frederiksberg, Nordre Fasanvej 57, DK-2000

Frederiksberg, Denmark.
\end{abstract}

Published online: 20 April 2020

Reference

1. Simpson, et al. Osteoarthritis Preoperative Package for care of Orthotics, Rehabilitation, Topical and oral agent Usage and Nutrition to Improve ouTcomes at a Year (OPPORTUNITY); a feasibility study protocol for a randomised controlled trial. Trials. 2020;20:209. https://doi.org/10.1186/ s13063-019-3709-5.

C C The Author(s). 2020 Open Access This article is licensed under a Creative Commons Attribution 4.0 International License, which permits use, sharing, adaptation, distribution and reproduction in any medium or format, as long as you give appropriate credit to the original author(s) and the source, provide a link to the Creative Commons licence, and indicate if changes were made. The images or other third party material in this article are included in the article's Creative Commons licence, unless indicated otherwise in a credit line to the material. If material is not included in the article's Creative Commons licence and your intended use is not permitted by statutory regulation or exceeds the permitted use, you will need to obtain permission directly from the copyright holder. To view a copy of this licence, visit http://creativecommons.org/licenses/by/4.0/ The Creative Commons Public Domain Dedication waiver (http://creativecommons.org/publicdomain/zero/1.0/) applies to the data made available in this article, unless otherwise stated in a credit line to the data. 